\title{
Model Epidemik Penyebaran Malaria
}

\author{
Resmawan \\ Jurusan Matematika, Fakultas MIPA, Universitas negeri Gorontalo
}

\begin{abstract}
ABSTRAK
Dalam artikel ini dibahas model matematika penyebaran malaria tipe SEIRS - SEI. Modifikasi model dilakukan dengan pemberian perlakuan pada manusia, berupa vaksinasi dan pengobatan. Dalam model ini, populasi manusia dibagi menjadi empat kelas, yaitu rentan, terpapar, terinfeksi, dan pulih. Adapun populasi nyamuk dibagi menjadi tiga kelas, yaitu rentan, terpapar dan terinfeksi. Selanjutnya dilakukan analisis pada model untuk menunjukkan pengaruh perlakuan yang diberikan terhadap penularan penyakit. Pada bagian akhir dalam artikel ini diberikan simulasi numerik untuk menunjukkan efektifitas vaksinasi dan pengobatan pada manusia untuk menekan laju penularan penyakit. Hasil simulasi menunjukkan bahwa peningkatan efektifitas vaksinasi maupun pengobatan pada manusia mampu menurunkan angka bilangan reproduksi, sehingga dalam jangka waktu tertentu penyakit akan menghilang dari populasi.
\end{abstract}

Kata kunci: Model Epidemik, Malaria, SEIRS-SEI, Vaksinasi, Pengobatan.

\begin{abstract}
This article discusses the mathematical model of SEIRS-SEI type malaria spread. Modification of the model is done by giving the treatment in humans, in the form of vaccination and medication treatment. In this model, the human population is divided into four classes, namely susceptible, exposed, infected, and recovered. The mosquito population is divided into three classes, namely susceptible, exposed and infected. Furthermore, the analysis of the model to show the effect of treatment given to disease transmission. At the end of this article is provided numerical simulations to show the effectiveness of vaccination and treatment in humans to suppress the rate of transmission of disease. The simulation results show that the increase of vaccination effectiveness and medication treatment in humans can reduce the reproduction numbers, so that within a certain time the disease will disappear from the population.
\end{abstract}

Keywords: Epidemic Model, Malaria, Medication, SEIRS-SEI, Vaccination.

\section{Pendahuluan}

Malaria merupakan penyakit yang disebabkan oleh infeksi parasit dari Nyamuk Anopheles betina genus Plasmodium. Malaria dapat ditularkan melalui gigitan nyamuk yang terinfeksi, transfusi darah, pemakaian jarum suntik, maupun bawaan. Malaria tergolong penyakit yang sangat mematikan bagi manusia. Oleh karena itu, diperlukan perlakuan pencegahan untuk mengendalikannya baik tingkat infeksi maupun tingkat penyebaran penyakit ini. Berdasarkan beberapa kasus malaria yang telah terjadi, muncul berbagai penelitian yang mengontruksikan sebuah model matematika untuk malaria. Pemodelan matematika dapat membantu memahami dan mengidentifikasi hubungan penyebaran penyakit malaria dengan berbagai parameter epidemiologi, membantu dalam perencanaan masa depan dan mempertimbangkan langkah-langkah pengendalian yang tepat.

Beberapa penelitian sebelumnya yang membahas model penyebaran malaria dapat dilihat pada [1][2]. Modifikasi model dilakukan dengan penambahan kelas terpapar (exposed) pada kedua populasi dengan mengacu pada [3]. Hal ini diperlukan karena sporozoid yang dihasilkan dari gigitan nyamuk terinfeksi memerlukan masa inkubasi selama 9-14 hari untuk benar-benar menimbulkan penyakit [4]. Selama masa inkubasi ini, populasi dikelompokkan ke dalam kelas terpapar (exposed), sehingga model ini disebut SEIRSSEI. Modifikasi model juga dilakukan dengan penambahan parameter perlakuan berupa vaksinasi pada manusia. Vaksinasi yang diberikan dapat membuat manusia rentan yang telah tergigit dapat langsung berpindah ke manusia pulih. Dalam hal ini diasumsikan bahwa manusia pada kelas rentan $\left(S_{h}\right)$ dapat berpindah ke kelas pulih $\left(R_{h}\right)$ karena adanya vaksinasi dengan laju $\theta$ [5]. Tujuan dari penelitian ini adalah untuk mengonstruksi model matematika penularan penyakit malaria dengan memperhatikan faktor perlakuan berupa vaksinasi dan pengobatan pada manusia.. Selanjutnya akan dilakukan analisis model dan simulasi dengan komputasi numerik untuk melihat efektifitas vaksinasi dan pengobatan pada manusia untuk menekan laju penularan penyakit. 


\section{Model Matematika}

Secara skematis, pola penyebaran penyakit malaria pada model ini digambarkan dalam diagram kompartemen pada Gambar 1, dengan persamaan dinamika sistem sebagai berikut

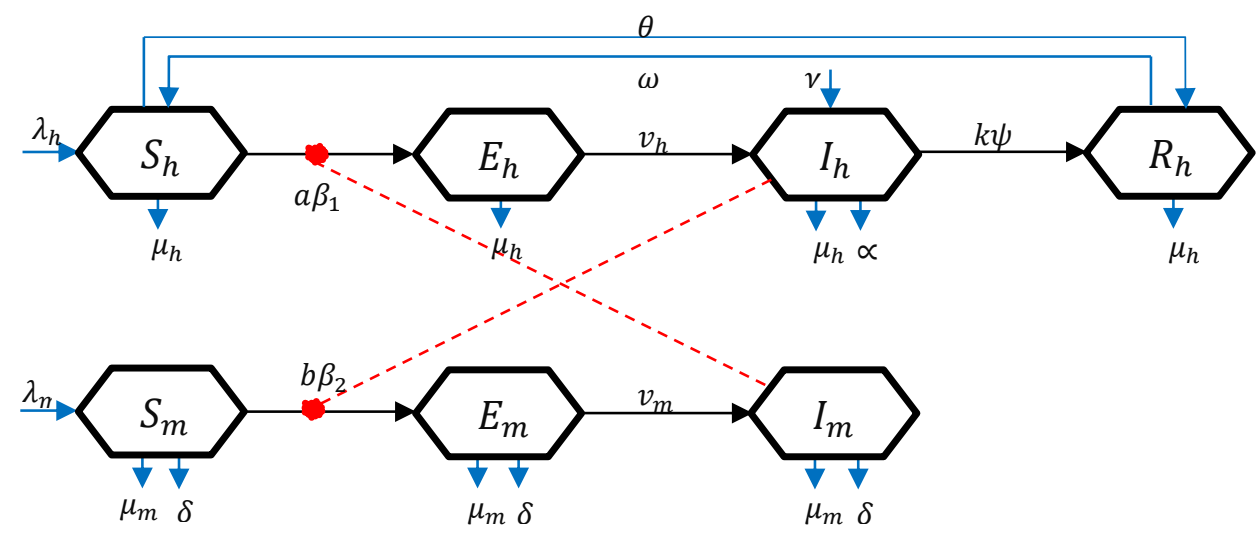

Gambar 1. Diagram kompartemen penyakit malaria tipe SEIRS-SEI dengan vaksinasi dan pengobatan

Dengan demikian, persamaan dinamika sistem tersebut diformulasikan sebagai berikut :

$$
\left\{\begin{array}{l}
\frac{d S_{h}}{d t}=\lambda_{h}+\omega R_{h}-a \beta_{1} I_{m} S_{h}-\left(\theta+\mu_{h}\right) S_{h} \\
\frac{d E_{h}}{d t}=a \beta_{1} I_{m} S_{h}-\left(v_{h}+\mu_{h}\right) E_{h} \\
\frac{d I_{h}}{d t}=v_{h} E_{h}+\gamma I_{h}-\left(\mu_{h}+\alpha+k \psi\right) I_{h} \\
\frac{d R_{h}}{d t}=k \psi I_{h}-\left(\mu_{h}+\omega\right) R_{h}+\theta S_{h} \\
\frac{d S_{m}}{d t}=\lambda_{m}-\left(b \beta_{2} I_{h}+\mu_{m}+\delta\right) S_{m} \\
\frac{d E_{m}}{d t}=b \beta_{2} I_{h} S_{m}-\left(v_{m}+\mu_{m}+\delta\right) E_{m} \\
\frac{d I_{m}}{d t}=v_{m} E_{m}-\left(\mu_{m}+\delta\right) I_{m}
\end{array}\right.
$$

Variabel dan parameter yang digunakan disajikan pada Tabel 1 dan Tabel 2.

Tabel 1. Variabel pada model malaria tipe SEIRS-SEI dengan vaksinasi dan pengobatan

\begin{tabular}{cl}
\hline Variabel & \multicolumn{1}{c}{ Keterangan } \\
\hline$S_{h}(t)$ & Banyaknya manusia yang rentan terkena penyakit malaria pada waktu $t$ \\
$E_{h}(t)$ & Banyaknya manusia yang terpapar penyakit malaria pada waktu $t$ \\
$I_{h}(t)$ & Banyaknya manusia yang terinfeksi penyakit malaria pada waktu $t$ \\
$R_{h}(t)$ & Banyaknya manusia yang sembuh dari penyakit malaria pada waktu $t$ \\
$S_{m}(t)$ & Banyaknya nyamuk yang rentan terkena penyakit malaria pada waktu $t$ \\
$E_{m}(t)$ & Banyaknya nyamuk yang terpapar penyakit malaria pada waktu $t$ \\
$I_{m}(t)$ & Banyaknya nyamuk yang terinfeksi penyakit malaria pada waktu $t$ \\
\hline
\end{tabular}

Tabel 2. Parameter pada model malaria tipe SEIRS-SEI dengan vaksinasi dan pengobatan

\begin{tabular}{clc}
\hline Parameter & \multicolumn{1}{c}{ Keterangan } & Satuan \\
\hline$\lambda_{h}$ & Laju kelahiran dan migrasi manusia & orang $\times$ waktu $^{-1}$ \\
$\lambda_{m}$ & Laju kelahiran dan migrasi nyamuk & nyamuk $\times$ waktu $^{-1}$ \\
$\mu_{h}$ & Laju konstan kematian manusia secara alami & waktu $^{-1}$ \\
\hline
\end{tabular}




\begin{tabular}{|c|c|c|}
\hline$\mu_{m}$ & Laju konstan kematian nyamuk secara alami & waktu $^{-1}$ \\
\hline$a$ & $\begin{array}{l}\text { Rata-rata banyaknya gigitan nyamuk terinfeksi pada } \\
\text { manusia rentan tiap satuan waktu }\end{array}$ & nyamuk $^{-1} \times$ waktu $^{-1}$ \\
\hline$b$ & $\begin{array}{l}\text { Rata-rata banyaknya gigitan nyamuk rentan pada manusia } \\
\text { terinfeksi tiap satuan waktu }\end{array}$ & orang $^{-1} \times$ waktu $^{-1}$ \\
\hline$\beta_{1}$ & $\begin{array}{l}\text { Peluang terjadinya transmisi penyakit dari nyamuk } \\
\text { terinfeksi ke manusia rentan }\end{array}$ & tanpa satuan \\
\hline$\beta_{2}$ & $\begin{array}{l}\text { Peluang terjadinya transmisi penyakit dari manusia } \\
\text { terinfeksi ke nyamuk rentan }\end{array}$ & tanpa satuan \\
\hline$\delta$ & Efektivitas penyemprotan pada nyamuk & \\
\hline$\omega$ & $\begin{array}{l}\text { Laju konstan hilangnya kekebalan tubuh pada manusia } \\
\text { setelah pulih }\end{array}$ & $\begin{array}{l}\text { waktu } \\
\text { waktu }^{-1}\end{array}$ \\
\hline$\theta$ & Efektivitas vaksinasi pada manusia & \\
\hline$\gamma$ & Laju bayi yang lahir dari ibu yang terinfeksi Malaria & waktu $^{-1}$ \\
\hline$\psi$ & Efektivitas pengobatan pada manusia & tanpa satuan \\
\hline$\alpha$ & Laju kematian manusia akibat malaria & waktu $^{-1}$ \\
\hline$k$ & Laju pemulihan manusia & waktu $^{-1}$ \\
\hline$v_{h}$ & Laju perpindahan manusia terpapar ke manusia terinfeksi. & waktu $^{-1}$ \\
\hline$v_{m}$ & Laju perpindahan nyamuk terpapar ke nyamuk terinfeksi. & waktu $^{-1}$ \\
\hline
\end{tabular}

\subsection{Titik Tetap}

\section{Analisis Model}

Titik tetap diperoleh dengan menyelesaikan sistem (1), yaitu kondisi yang diperoleh pada saat $\frac{d S_{h}}{d t}=$ $\frac{d E_{h}}{d t}=\frac{d I_{h}}{d t}=\frac{d R_{h}}{d t}=\frac{d S_{m}}{d t}=\frac{d E_{m}}{d t}=\frac{d I_{m}}{d t}=0$. Dari persamaan (1), diperoleh titik tetap bebas penyakit (disease-free equilibrium),

$$
\boldsymbol{x}_{d f e}\left(S_{h}, E_{h}, I_{h}, R_{h}, S_{m}, E_{m}, I_{m}\right)=\left(S_{h}^{*}, 0,0, R_{h}^{*}, S_{m}^{*}, 0,0\right)
$$

dengan

dan titik tetap endemik

$$
S_{h}^{*}=\frac{\lambda_{h}\left(\omega+\mu_{h}\right)}{\mu_{h}\left(\mu_{h}+\omega+\theta\right)}, \quad R_{h}^{*}=\frac{\theta \lambda_{h}}{\mu_{h}\left(\mu_{h}+\omega+\theta\right)}, \quad S_{m}^{*}=\frac{\lambda_{m}}{\delta+\mu_{m}}
$$

$$
\boldsymbol{x}_{e e}\left(S_{h}, E_{h}, I_{h}, R_{h}, S_{m}, E_{m}, I_{m}\right)=\left(S_{h}^{* *}, E_{h}^{* *}, I_{h}^{* *}, R_{h}^{*}, S_{m}^{* *}, E_{m}^{* *}, I_{m}^{* *}\right)
$$

dengan

$$
\begin{array}{rlrl}
S_{h}^{* *} & =\frac{\lambda_{h}+\omega R_{h}}{a \beta_{1} I_{m}+\theta+\mu_{h}} & S_{m}^{* *} & =\frac{\lambda_{m}}{b \beta_{2} I_{h}+\delta+\mu_{m}} \\
E_{h}^{* *} & =\frac{a \beta_{1} I_{m} S h}{v_{h}+\mu_{h}} & E_{m}^{* *} & =\frac{b \beta_{2} I_{h} S_{m}}{v_{m}+\delta+\mu_{m}} \\
I_{h}^{* *} & =\frac{v_{h} E_{h}}{\alpha-\gamma+\mu_{h}+k \psi} & I_{m}^{* *} & =\frac{v_{m} E_{m}}{\delta+\mu_{m}} \\
R_{h}^{* *} & =\frac{\theta S_{h}+k \psi I_{h}}{\omega+\mu_{h}} &
\end{array}
$$

\subsection{Bilangan Reproduksi}

Bilangan reproduksi yang dinotasikan dengan $\mathcal{R}_{0}$ adalah nilai harapan banyaknya infeksi tiap satuan waktu. Infeksi ini terjadi pada suatu populasi rentan yang dihasilkan oleh satu individu terinfeksi. Bilangan reproduksi dasar ditentukan dengan mengacu pada [6], contoh lain dapat ditemukan pada [7]. Berdasarkan sistem persamaan (1), diperoleh bilangan reproduksi 
dimana

$$
\mathcal{R}_{0}=\sqrt{K_{1} K_{2}}
$$

$$
K_{1}=\frac{b \beta_{2} \lambda_{m}}{\left(\delta+\mu_{m}\right)\left(\mu_{h}+\alpha+k \psi-\gamma\right)} \text { dan } K_{2}=\frac{a \beta_{1} \lambda_{h}\left(\omega+\mu_{h}\right)}{\mu_{h}\left(\mu_{h}+\omega+\theta\right)\left(\mu_{m}+\delta\right)}
$$

Persamaan (15) merupakan nilai ambang batas epidemik yang akan menjadi tolak ukur tingkat penyebaran malaria dalam populasi. Kondisi yang memungkinkan dari bilangan reproduksi menurut van den Driessche \& Watmough [8] adalah:

1. Jika $\mathcal{R}_{0}<1$, maka jumlah individu yang terinfeksi akan menurun pada setiap generasi, sehingga penyakit akan menghilang.

2. Jika $\mathcal{R}_{0}>1$, maka jumlah individu yang terinfeksi akan meningkat pada setiap generasi, sehingga penyakit akan meningkat dan mewabah.

\subsection{Analisis Kestabilan}

Pada bagian ini, dilakukan analisis untuk melihat sifat kestabilan pada titik tetap tanpa penyakit $\left(x_{d f e}\right)$.

\subsubsection{Matriks Jacobi untuk Titik Tetap Tanpa Penyakit}

Sifat kestabilan titik tetap tanpa penyakit $\left(\boldsymbol{x}_{d f e}\right)$, dapat ditemukan dengan melakukan pelinearan pada sistem persamaan diferensial (5.8) di sekitar $\boldsymbol{x}_{d f e}$, sehingga diperoleh matriks Jacobi untuk titik tetap tanpa penyakit sebagai berikut

dengan

$$
J_{X_{\text {dfe }}}=\left(\begin{array}{ccccccc}
J_{11} & 0 & 0 & J_{14} & 0 & 0 & J_{17} \\
0 & J_{22} & 0 & 0 & 0 & 0 & J_{27} \\
0 & J_{32} & J_{33} & 0 & 0 & 0 & 0 \\
J_{41} & 0 & J_{43} & J_{44} & 0 & 0 & 0 \\
0 & 0 & J_{53} & 0 & J_{55} & 0 & 0 \\
0 & 0 & J_{63} & 0 & 0 & J_{66} & 0 \\
0 & 0 & 0 & 0 & 0 & J_{76} & J_{77}
\end{array}\right)
$$

$$
\begin{aligned}
J_{11} & =-\theta-\mu_{h} & J_{43} & =k \psi \\
J_{14} & =\omega & J_{44} & =-\mu_{h}-\omega \\
J_{17} & =\frac{a \beta_{1} \lambda_{h} \omega \theta}{\left(\theta+\mu_{h}\right)\left(\mu_{h}^{2}+\omega \mu_{h}+\theta \mu_{h}\right)}-\frac{a \beta_{1} \lambda_{h}}{\theta+\mu_{h}} & J_{53} & =-\frac{b \beta_{2} \lambda_{m}}{\delta+\mu_{m}} \\
J_{22} & =-v_{h}-\mu_{h} & J_{55} & =-\delta-\mu_{m} \\
J_{27} & =\frac{a \beta_{1} \lambda_{h} \omega \theta}{\left(\theta+\mu_{h}\right)\left(\mu_{h}^{2}+\omega \mu_{h}+\theta \mu_{h}\right)}+\frac{a \beta_{1} \lambda_{h}}{\theta+\mu_{h}} & J_{63} & =\frac{b \beta_{2} \lambda_{m}}{\delta+\mu_{m}} \\
J_{32} & =v_{h} & J_{66} & =-v_{m}-\delta-\mu_{m} \\
J_{33} & =-\alpha+\gamma-\mu_{h}-k \psi & J_{76} & =v_{m} \\
J_{41} & =\theta & J_{77} & =-\delta-\mu_{m}
\end{aligned}
$$

\subsubsection{Nilai Eigen}

Titik tetap tanpa penyakit $\left(\boldsymbol{x}_{\boldsymbol{d} \boldsymbol{e} \boldsymbol{e}}\right)$ bersifat stabil jika dan hanya jika setiap nilai eigen dari matriks $\boldsymbol{J}_{\boldsymbol{X}_{\boldsymbol{d f e}}}$ bernilai negatif dan tidak stabil jika dan hanya jika ada minimal satu nilai eigen dari matriks $\boldsymbol{J}_{\boldsymbol{X}_{\boldsymbol{d} \boldsymbol{f}}}$ yang tak negatif.

Berdasarkan matriks $\left|\boldsymbol{J}_{\boldsymbol{X}_{\boldsymbol{d f}}}-\boldsymbol{\xi} \boldsymbol{I}\right|$, diperoleh tujuh nilai eigen. Tiga diantaranya diperoleh dari persamaan karakteristik,

yaitu

$$
\left(\xi^{2}-\left(J_{11}+J_{44}\right) \xi+\left(J_{11} J_{44}-J_{14} J_{41}\right)\right)\left(\xi-J_{55}\right)=0
$$

dengan

$$
\begin{aligned}
& \xi_{1}=J_{55}=-\delta-\mu_{m} \\
& \xi_{2}=\frac{1}{2} a_{1}+\frac{1}{2} \sqrt{a_{1}^{2}-4 a_{2}} \\
& \xi_{3}=\frac{1}{2} a_{1}-\frac{1}{2} \sqrt{a_{1}^{2}-4 a_{2}}
\end{aligned}
$$

$$
\begin{aligned}
& a_{1}=J_{11}+J_{44}=-\theta-\mu_{h}+\omega \\
& a_{2}=J_{11} J_{44}-J_{14} J_{41}=\mu_{h}^{2}+(\omega+\theta) \mu_{h}
\end{aligned}
$$


Sementara empat nilai eigen lainnya adalah akar-akar dari persamaan karakteristik:

dengan koefisien karakteristik

$$
\xi^{4}+A_{1} \xi^{3}+A_{2} \xi^{2}+A_{3} \xi+A_{4}=0
$$

$$
\begin{aligned}
& A_{1}=-\left(J_{22}+J_{33}+J_{66}+J_{77}\right) \\
& A_{2}=J_{22} J_{33}+J_{22} J_{66}+J_{22} J_{77}+J_{33} J_{66}+J_{33} J_{77}+J_{66} J_{77} \\
& A_{3}=-\left(J_{22} J_{33} J_{66}+J_{22} J_{33} J_{77}+J_{22} J_{66} J_{77}+J_{33} J_{66} J_{77}\right) \\
& A_{4}=J_{22} J_{33} J_{66} J_{77}-J_{27} J_{32} J_{63} J_{76}
\end{aligned}
$$

Penentuan nilai eigen dapat dilihat pada Lampiran 4.

Sistem dapat dikatakan stabil jika semua nilai eigen bernilai negatif. Oleh sebab itu:

a. Untuk nilai eigen $\xi_{1}$

$\xi_{1}<0$, karena semua parameter positif

b. Untuk Nilai eigen $\xi_{2}$

$\checkmark a_{2}>0$ karena semua parameter bernilai positif

$\checkmark \xi_{2}<0$ jika $a_{1}<0$ dan $a_{1}>\sqrt{a_{1}^{2}-4 a_{2}}$

$\checkmark a_{1}<0$ jika $\theta>\omega$ atau $\mu_{h}>\omega$

c. Untuk Nilai eigen $\xi_{3}$

$\checkmark \xi_{3}<0$ jika $a_{1}<0$

$\checkmark \quad a_{1}<0$ jika $\theta>\omega$ atau $\mu_{h}>\omega$

Selanjutnya, dilakukan evaluasi tanda dari keempat nilai eigen pada persamaan karakteristik

(5.10), dengan menggunakan kriteria Routh-Horwitz.

Berdasarkan kriteria Routh-Horwitz, $\xi_{1}, \xi_{2}, \xi_{3}$, dan $\xi_{4}$ pada persamaan (5.10) akan bernilai negatif apabila:

1. $A_{1}>0$

Berdasarkan bersamaan karakteristik (5.10), diperoleh koefisien

$-\left(J_{22}+J_{33}+J_{66}+J_{77}\right)$

dimana

$\begin{array}{ll}J_{22}=-v_{h}-\mu_{h} & J_{33}=-\alpha+\gamma-\mu_{h}-k \psi ; \\ J_{66}=-v_{m}-\delta-\mu_{m} & J_{77}=-\delta-\mu_{m}\end{array}$

Dengan demikian, $A_{1}>0$ karena semua parameter positif.

2. $A_{3}>0$

Berdasarkan bersamaan karakteristik (5.10), diperoleh koefisien

$-\left(J_{22} J_{33} J_{66}+J_{22} J_{33} J_{77}+J_{22} J_{66} J_{77}+J_{33} J_{66} J_{77}\right)$

Dengan asumsi yang sama bahwa semua parameter bernilai positif, meyebabkan koefisien $J_{22}, J_{33}, J_{66}$, dan $J_{77}$ bernilai negatif. Dengan demikian, $A_{3}>0$.

3. $A_{4}>0$

Berdasarkan bersamaan karakteristik (5.10), diperoleh koefisien

$A_{4}=J_{22} J_{33} J_{66} J_{77}-J_{27} J_{32} J_{63} J_{76}$

Karena semua nilai parameter positif, maka $A_{4}>0$ akan terpenuhi jika

4. $A_{1} A_{2} A_{3}-A_{1}^{2} A_{4}-A_{3}^{2}>0$

$$
J_{22} J_{33} J_{66} J_{77}>J_{27} J_{32} J_{63} J_{76}
$$

Telah diketahui bahwa $A_{1}>0$ dan $A_{3}>0$ dan $A_{4}>0$. Selanjutnya dengan asumsi yang sama, jelas bahwa $A_{2}>0$ berdasarkan persamaan

$$
A_{2}=J_{22} J_{33}+J_{22} J_{66}+J_{22} J_{77}+J_{33} J_{66}+J_{33} J_{77}+J_{66} J_{77}
$$

Dengan demikian, $A_{1} A_{2} A_{3}-A_{1}^{2} A_{4}-A_{3}^{2}>0$ akan terpenuhi jika

$$
A_{1} A_{2} A_{3}>A_{1}^{2} A_{4}+A_{3}^{2}
$$

\subsection{Nilai Parameter}

\section{Simulasi Numerik}

Pada bagian simulasi ini, diamati dinamika populasi dalam kondisi ketika $\mathcal{R}_{0}<1$. Dalam hal ini, $\mathcal{R}_{0}$ merupakan bilangan reproduksi yang didefinisikan pada persamaan (15). Simulasi dilakukan untuk menunjukkan adanya pengaruh treatment berupa pengobatan dan vaksinasi pada manusia terhadap dinamika populasi manusia dan populasi nyamuk. Pemilihan parameter didasarkan pada studi yang dilakukan oleh berbagai sumber terpercaya. Beberapa nilai parameter seperti yang 
menyangkut populasi, didasarkan pada asumsi tentang situasi penyakit yang paling umum dan disajikan pada Tabel 3.

Tabel 3. Nilai parameter pada model malaria tipe SEIRS-SEI

\begin{tabular}{|c|c|c|c|}
\hline Parameter & Nilai Parameter & Satuan & Sumber \\
\hline$\lambda_{h}$ & 0.027 & orang $\times$ hari $^{-1}$ & {$[9]$} \\
\hline$\lambda_{m}$ & 0.13 & nyamuk $\times$ hari $^{-1}$ & Asumsi \\
\hline$\mu_{h}$ & 0.004 & hari $^{-1}$ & [9] \\
\hline$\mu_{m}$ & 0.04 & hari $^{-1}$ & [9] \\
\hline$a$ & 4.3 & nyamuk $^{-1} \times$ hari $^{-1}$ & {$[9]$} \\
\hline$b$ & 0.33 & orang $^{-1} \times$ hari $^{-1}$ & [9] \\
\hline$\beta_{1}$ & 0.010 & tanpa satuan & [10] \\
\hline$\beta_{2}$ & 0.072 & tanpa satuan & [10] \\
\hline$\delta$ & 0.01 & tanpa satuan & Asumsi \\
\hline$\omega$ & $1 / 730$ & hari $^{-1}$ & [9] \\
\hline$\theta$ & 0.1 & tanpa satuan & Asumsi \\
\hline$\gamma$ & 0.005 & hari $^{-1}$ & Asumsi \\
\hline$\psi$ & 0.1 & tanpa satuan & Asumsi \\
\hline$\alpha$ & 0.005 & hari $^{-1}$ & [9] \\
\hline$k$ & 0.611 & hari $^{-1}$ & {$[107$} \\
\hline$v_{h}$ & 0.1 & hari $^{-1}$ & [9] \\
\hline$v_{m}$ & 0.083 & hari $^{-1}$ & [10] \\
\hline
\end{tabular}

Simulasi dilakukan dengan menggunakan nilai parameter pada Tabel 3, dengan nilai awal populasi manusia rentan $\left(S_{h}\right)$ adalah 300 , populasi manusi terpapar $\left(E_{h}\right)$ adalah 50 , populasi manusia terinfeksi $\left(I_{h}\right)$ adalah 10 , populasi manusi pulih $\left(R_{h}\right)$ adalah 0 , populasi nyamuk rentan $\left(S_{m}\right)$ adalah 2000, populasi nyamuk terpapar $\left(E_{m}\right)$ adalah 100 dan populasi nyamuk terinfeksi $\left(I_{m}\right)$ adalah 50 .

\subsection{Dinamika Populasi dalam Keadaan Bebas Penyakit}

Dengan linearisasi dan perhitungan terhadap sistem (5.1) disekitar titik tetap pada kondisi bebas penyakit atau $\mathcal{R}_{0}<1$, diperoleh matriks jacobian dan nilai eigen untuk titik tetap bebas penyakit. Matriks jacobian dan titik tetap tanpa penyakit diperoleh dari solusi numerik sistem dengan menggunakan software berbasis fungsional. Solusi diperoleh dengan menggunakan nilai parameter pada Tabel 5 dengan nilai bilangan reproduksi dasar sebesar $\mathcal{R}_{0}=0.53$. Titik tetap bebas penyakit tersebut adalah

$$
x_{d f e}=(0.34,0,0,6.41,2.60,0,0)
$$

Untuk melihat kestabilan titik tetap ini, diperlukan matriks jacobi disekitar titik tetap, kemudian mengamati nilai eigen yang diperoleh. Sistem dikatakan stabil di sekitar titik tetap bebas penyakit apabila semua nilai eigen yang diperoleh bertanda negatif. Berdasarkan nilai-nilai parameter pada Tabel 5 dan persamaan (5.1), diperoleh matriks jacobi di sekitar titik tetap, yaitu

$$
J_{X_{\text {dfe }}}=\left(\begin{array}{ccccccc}
-0.104 & 0 & 0 & 1 / 730 & 0 & 0 & -0.015 \\
0 & -0.104 & 0 & 0 & 0 & 0 & 0.015 \\
0 & 0.1 & -0.065 & 0 & 0 & 0 & 0 \\
0.1 & 0 & 0.0611 & -0.0054 & 0 & 0 & 0 \\
0 & 0 & -0.062 & 0 & -0.05 & 0 & 0 \\
0 & 0 & 0.062 & 0 & 0 & -0.13 & 0 \\
0 & 0 & 0 & 0 & 0 & 0.083 & -0.05
\end{array}\right)
$$

Dari matriks tersebut, diperoleh nilai eigen sebagai berikut

$$
\begin{array}{ll}
\xi_{1}=-0.15 & \xi_{5}=-0.05 \\
\xi_{2}=-0.11 & \xi_{6}=-0.03 \\
\xi_{3}=-0.09-0.04 i & \xi_{7}=-0.004 \\
\xi_{4}=-0.09+0.04 i &
\end{array}
$$

Hal ini menunjukkan bahwa sistem dalam keadaan stabil di sekitar titik tetap bebas penyakit. 
Dinamika populasi dengan beberapa nilai awal yang diberikan dalam kasus ini ditunjukkan pada Gambar 6. Berdasarkan gambar ini, dapat dipastikan bahwa solusi sistem mendekati titik tetap bebas penyakit atau stabil di sekitar titik tetap bebas penyakit pada saat $\mathcal{R}_{0}<1$.
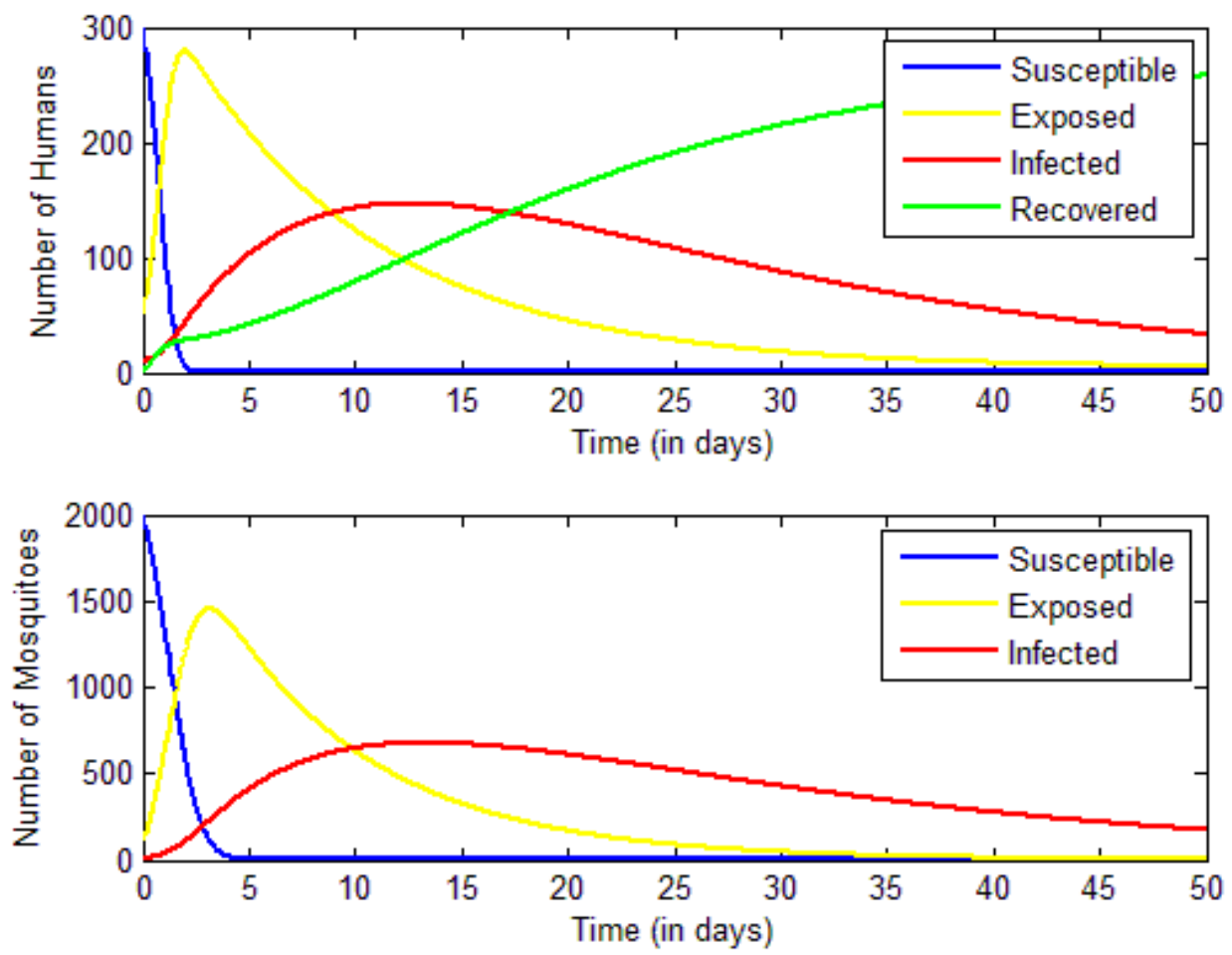

Gambar 6. Dimanika populasi model SEIRS-SEI pada kondisi $\mathcal{R}_{0}<1$

Gambar 6 menampilkan dinamika populasi dari kondisi awal menuju kondisi bebas penyakit. Masing-masing subpopulasi mengalami dinamika atau perubahan dari kondisi awal menuju titik di sekitar titik tetap bebas penyakit. Sub populasi manusia rentan mengalami penurunan karena terpapar oleh subpopulasi nyamuk terinfeksi. Demikian juga dengan subpopulasi nyamuk rentan mengalami penurunan karena terpapar oleh manusia terinfeksi. Kondisi ini menyebabkan adanya peningkatan pada subpopulasi terpapar dan terinfeksi dari kedua spesies. Peningkatan ini terjadi sejak hari pertama hingga disekitar hari ke-13. Setelah melalewati hari ke-13 terlihat, subpopulasi terpapar dan terinfeksi dari kedua spesies mengalami penurunan menuju titik bebas penyakit. Hal ini seiring dengan peningkatan subpopulasi manusia yang pulih dari penyakit, sehingga penyakit akan menghilang dari populasi.

\subsection{Simulasi Efektifitas Pengobatan pada Manusia}

Pada bagian ini, dilakukan simulasi untuk menunjukkan adanya kontribusi pengobatan pada manusia dalam menekan laju penularan penyakit. Dalam hal ini, dilakukan perubahan pada paramater efektifitas pengobatan pada manusia $(\psi)$. Akan ditunjukkan bahwa perubahan nilai pada parameter $\psi$ dapat mengubah nilai bilangan reproduksi $\left(\mathcal{R}_{0}\right)$ yang didefinisikan pada persamaan (15). Terdapat tiga nilai $\psi$ yang diamati, diambil pada selang $[0.10,0.50]$ dengan langkah 0.20 . Adapun nilai-nilai parameter lain dapat dilihat pada Tabel 3. Perubahan nilai parameter $\psi$ yang menyebabkan terjadinya perubahan nilai bilangan reproduksi dapat dilihat pada Tabel 4 .

Tabel 4 Hasil simulasi efektifitas pengobatan pada manusia terhadap bilangan reproduksi

\begin{tabular}{cc} 
Parameter $\psi$ & Bilangan reproduksi \\
\hline$\psi=0.10$ & $\mathcal{R}_{0}=0.53$ \\
$\psi=0.30$ & $\mathcal{R}_{0}=0.31$ \\
$\psi=0.50$ & $\mathcal{R}_{0}=0.24$ \\
\hline
\end{tabular}


Pada populasi manusia yang ditunjukkan pada Gambar 2. Jika efektifitas pengobatan pada manusia ditingkatkan, maka banyaknya manusia terpapar dan terinfeksi mengalami penurunan, sementara manusia yang pulih dari penyakit mengalami peningkatan.
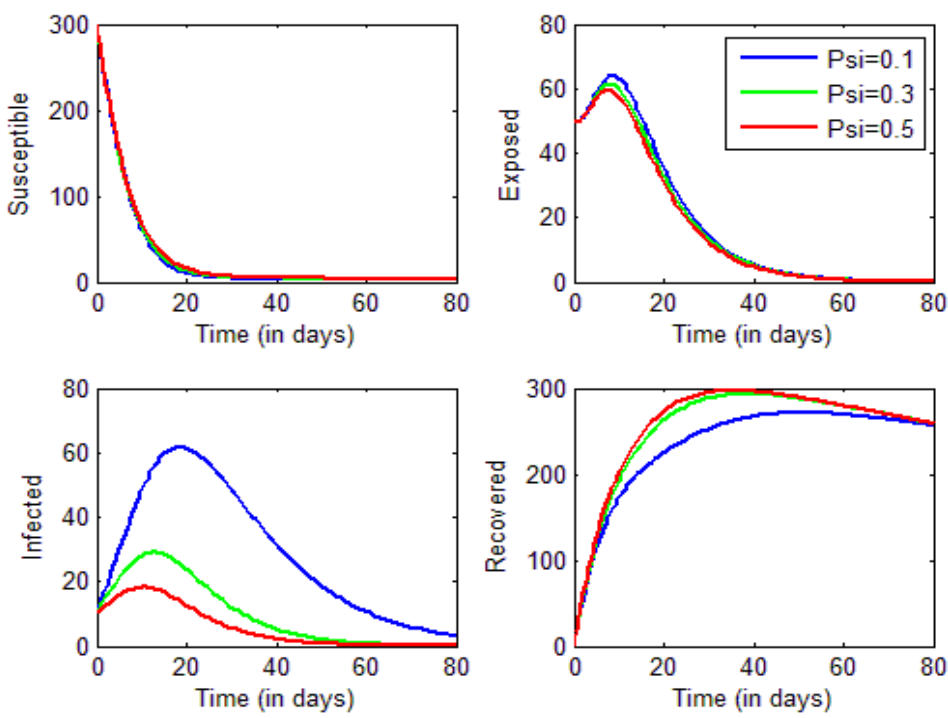

Gambar 2. Dinamika populasi manusia karena adanya pengobatan

Pengobatan yang diberikan pada manusia juga berdampak pada populasi nyamuk, sebagaimana ditunjukkan pada Gamba 3. Jika efektifitas pengobatan pada manusia ditingkatkan, maka populasi nyamuk pada kelas terpapar dan terinfeksi mengalami penurunan. Hal ini menyebabkan jumlah nyamuk pada populasi rentan mengalami peningkatan.
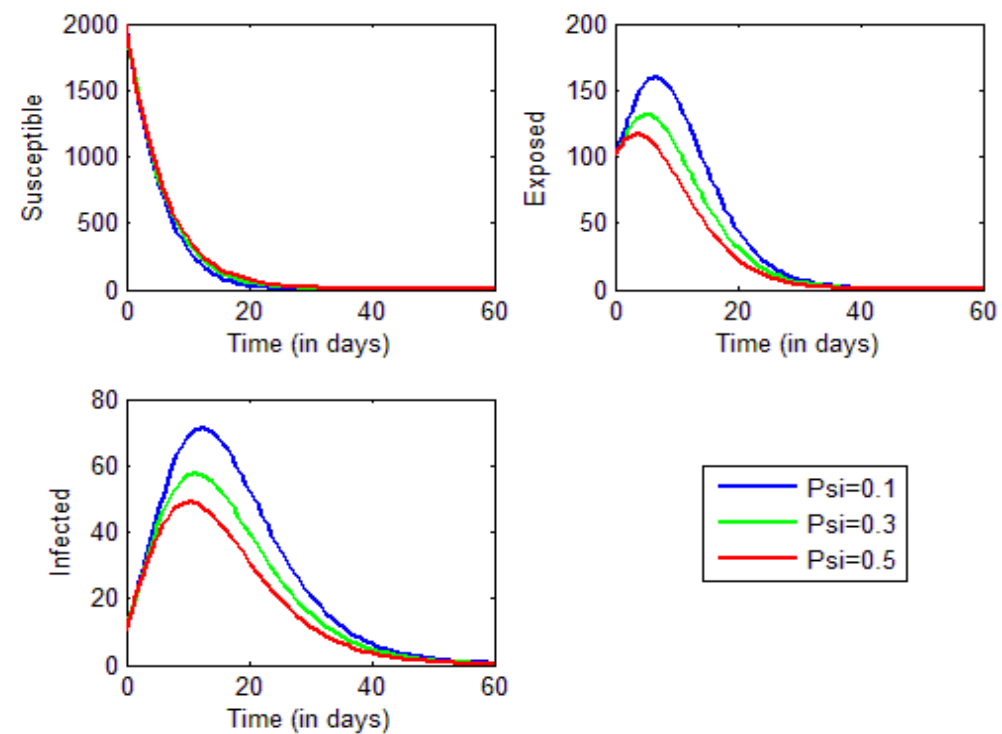

Gambar 3. Dinamika populasi nyamuk karena adanya pengobatan pada manusia

Adanya perubahan jumlah manusia dan nyamuk pada masing-masing kelas subpopulasi cenderung berbeda untuk setiap kenaikan efektifitas pengobatan pada manusia. Maksimum banyaknya manusia dan nyamuk terpapar terjadi pada sekitar hari ke-9, sementara maksimum banyaknya manusia dan nyamuk terinfeksi terjadi pada hari ke-20 dan ke-15. Hal ini sejalan dengan teori bahwa manusia yang terpapar akan mengalami masa inkubasi selama kurang lebih 14 hari kemudian benar-benar terinfeksi. Pada hari ke-20, dengan efektifitas pengobatan pada manusia ditingkatkan sebesar $40 \%$ dapat menurunkan populasi manusia terinfeksi sebesar $13,88 \%$ dari total populasi manusia dan dengan efektifitas pengobatan yang sama, pada hari ke-15 dapat menurunkan populasi nyamuk terinfeksi sebesar $1.43 \%$ dari total populasi nyamuk. 
Efektifitas pengobatan dalam menekan laju penularan penyakit ditunjukkan dengan dinamika populasi pada setiap sub kelas populasi. Dengan asumsi awal populasi sebagaimana yang disebutkan pada sub bagian 5.1, terlihat peningkatan efektifitas pengobatan tidak berpengaruh secara signifkan pada populasi rentan. Hal ini disebabkan karena perlakuan pengobatan tidak dilakukan secara langsung pada populasi rentan. Perubahan signifikan terjadi pada populasi manusia terinfeksi dimana penigkatan efektifitas pengobatan mempercepat laju penurunan manusia terinfeksi. Dengan efektifitas pengobatan sebesar 10\%, manusia terinfeksi mencapai 60 orang pada hari ke-20 kemudian mengalami penurunan hingga menjapai titik nol setelah melewati hari ke-80. Setelah dilakukan peningkatan efektifitas pengobatan hingga 50\%, populasi manusia terinfeksi hanya mencapai 15 orang pada hari ke-10 kemudian mengalami penurunan hingga mencapai titik nol pada hari ke-60. Dinamika ini berlaku sama pada populasi nyamuk dimana peningkatan efektifitas pengobatan pada manusia dapat menurunkan jumlah nyamuk terinfeksi dalam waktu yang lebih cepat. Hal ini menunjukkan bahwa peningkatan efektifitas pengobatan dapat mempercepat hilangnya penyakit dalam populasi.

\subsection{Simulasi Efektifitas Vaksinasi pada Manusia}

Pada bagian ini, dilakukan simulasi untuk menunjukkan adanya kontribusi vaksinasi pada manusia dalam menekan laju penularan penyakit. Dalam hal ini, dilakukan perubahan pada paramater efektifitas vaksinasi pada manusia $(\theta)$. Akan ditunjukkan bahwa perubahan nilai pada parameter $\theta$ dapat mengubah nilai bilangan reproduksi $\left(\mathcal{R}_{0}\right)$ yang didefinisikan pada persamaan (15). Terdapat tiga nilai $\theta$ yang diamati, diambil pada selang $[0.10,0.50]$ dengan langkah 0.20 . Adapun nilai-nilai parameter lain dapat dilihat pada Tabel 3. Perubahan nilai parameter $\theta$ yang menyebabkan terjadinya perubahan nilai bilangan reproduksi dapat dilihat pada Tabel 5 .

Tabel 5 Hasil simulasi efektifitas vaksinasi pada manusia terhadap bilangan reproduksi

\begin{tabular}{cc}
\hline Parameter $\theta$ & Bilangan reproduksi \\
\hline$\theta=0.10$ & $\mathcal{R}_{0}=0.53$ \\
$\theta=0.30$ & $\mathcal{R}_{0}=0.31$ \\
$\theta=0.50$ & $\mathcal{R}_{0}=0.24$ \\
\hline
\end{tabular}

Pada populasi manusia yang ditunjukkan pada Gambar 4, jika efektifitas vaksinasi pada manusia ditingkatkan, maka banyaknya manusia terpapar dan terinfeksi mengalami penurunan, sementara manusia yang pulih dari penyakit mengalami peningkatan. Hal ini disebabkan karena vaksinasi menyebabkan manusia rentan kebal dari penyakit.
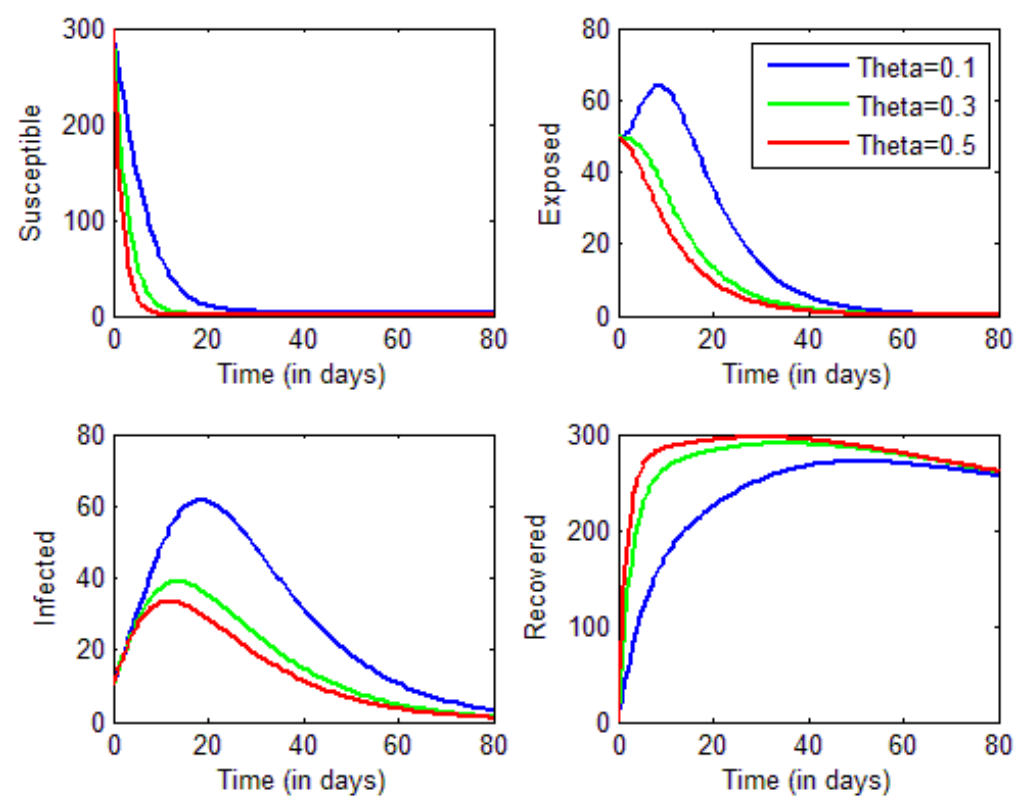
Gambar 4. Dinamika populasi manusia karena adanya vaksinasi

Vaksinasi yang diberikan pada manusia juga berdampak pada populasi nyamuk, sebagaimana ditunjukkan pada Gambar 5. Jika efektifitas vaksinasi pada manusia ditingkatkan, maka populasi nyamuk pada kelas terpapar dan terinfeksi mengalami penurunan. Hal ini disebabkan karena vaksinasi menyebabkan manusia terinfeksi berkurang. Dengan demikian, peluang nyamuk terpapar oleh manusia terinfeksi juga berkurang.
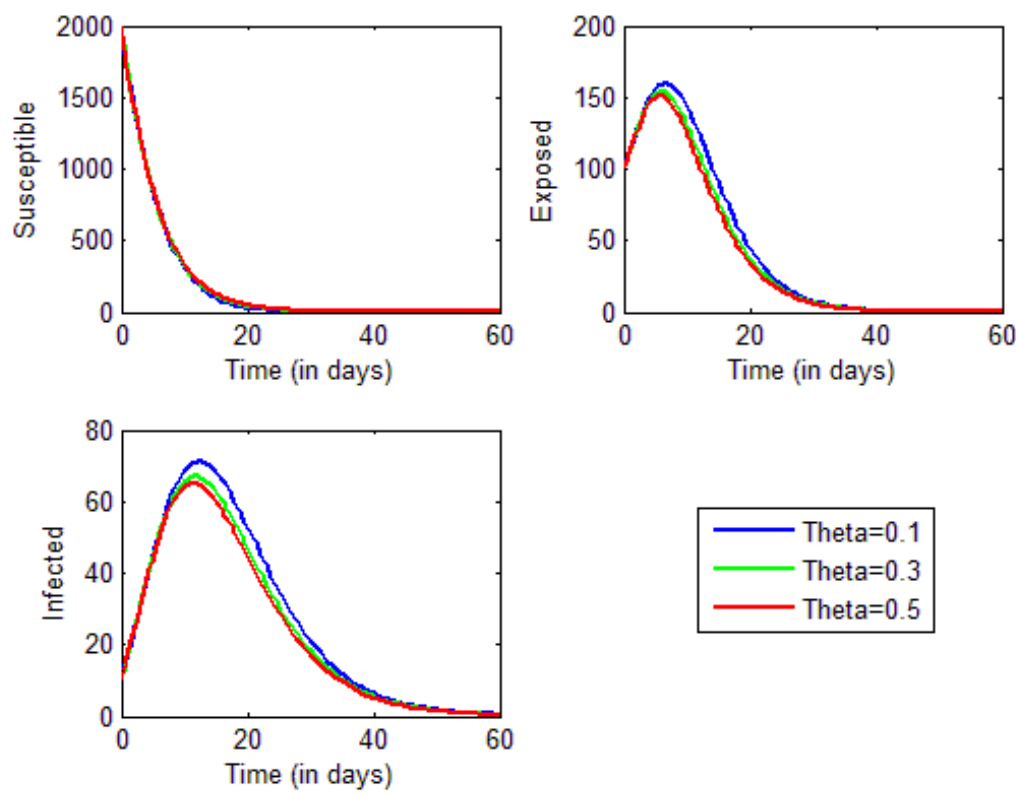

Gambar 5. Dinamika populasi nyamuk karena adanya vaksinasi pada manusia

Adanya perubahan jumlah manusia dan nyamuk pada masing-masing kelas subpopulasi cenderung berbeda untuk setiap kenaikan efektifitas vaksinasi pada manusia. Maksimum banyaknya manusia dan nyamuk terpapar terjadi pada sekitar hari ke-10, sementara maksimum banyaknya manusia dan nyamuk terinfeksi terjadi pada hari ke-20. Pada hari ke-20, dengan peningkatan efektifitas vaksinasi pada manusia sebesar $40 \%$ dapat menurunkan populasi manusia terinfeksi sebesar $12.50 \%$ dari total populasi manusia dan dapat menurunkan populasi nyamuk terinfeksi sebesar $0.47 \%$ dari total populasi nyamuk. Hal ini menunjukkan bahwa peningkatan efektifitas vaksinasi dapat mempercepat hilangnya penyakit dalam populasi. Adapun dampak vaksinasi terhadap nyamuk tidak begitu besar karena vaksinasi tidak berdampak langsung pada nyamuk. Vaksinasi hanya menurunkan jumlah manusia terinfeksi sehingga peluang nyamuk terpapar dari manusia terinfeksi menjadi lebih kecil.

Efektifitas vaksinasi dalam menekan laju penularan penyakit ditunjukkan dengan dinamika populasi pada setiap sub kelas populasi. Dengan asumsi awal populasi sebagaimana yang disebutkan pada sub bagian 5.1, terlihat peningkatan efektifitas vaksinasi tidak berpengaruh secara signifkan pada populasi nyamuk. Hal ini disebabkan karena perlakuan vaksinasi tidak berdampak secara langsung pada nyamuk. Perubahan signifikan terjadi pada populasi manusia dimana penigkatan efektifitas vaksinasi mempercepat laju penurunan manusia rentan, terpapar, dan terinfeksi serta mempercepat jumlah populasi manusia sembuh. Dinamika ini terjadi karena manusia yang divaksinasi akan berpindah ke kelas manusia sembuh setelah tergigit oleh nyamuk terinfeksi. Dengan efektifitas vaksinasi sebesar 10\%, manusia terinfeksi mencapai 60 orang pada hari ke-20 kemudian mengalami penurunan hingga menjapai titik nol setelah melewati hari ke-80. Setelah dilakukan peningkatan efektifitas vaksinasi hingga 50\%, populasi manusia terinfeksi hanya mencapai 15 orang pada hari ke-10 kemudian mengalami penurunan hingga mencapai titik nol, sementara populasi manusia sembuh mengalami peningkatan secara signifikan. Hal ini menunjukkan bahwa peningkatan efektifitas vaksinasi dapat mempercepat hilangnya penyakit dalam populasi. 


\section{Simpulan}

Model penyebaran penyakit malaria tipe SEIRS-SEI ini memiliki dua titik tetap yaitu titik tetap bebas penyakit dan titik tetap endemik. Hasil simulasi menunjukkan bahwa sistem dalam keadaan stabil disekitar titik tetap bebas penyakit pada kondisi $\mathcal{R}_{0}<1$. Perlakuan yang diberikan memiliki pengaruh terhadap dinamika populasi manusia dan nyamuk yang ditunjukkan dengan bilangan reproduksi. Secara umum, jika efektivitas perlakuan ditingkatkan maka bilangan reproduksi menurun. Hal tersebut menunjukkan bahwa jumlah individu yang terinfeksi semakin berkurang, sehingga penyakit tidak akan menyebar dan dalam jangka waktu tertentu penyakit akan menghilang dari populasi.

\section{Daftar Pustaka}

[1] R. Resmawan, P. Sianturi, and E. H. Nugrahani, "The Analysis of SEIRS-SEI Epidemic Models on Malaria with Regard to Human Recovery Rate," Aceh Int. J. Sci. Technol., vol. 6, no. 3, pp. 132-140, Mar. 2018, doi: 10.13170/aijst.6.3.9303.

[2] H. Laarabi, E. H. Labriji, M. Rachik, and A. Kaddar, "Optimal Control of an Epidemic Model with A Saturated Incidence Rate, Modelling and Control," J. Math. Biol, vol. 17, no. 4, pp. 448459, 2012.

[3] N. Chitnis, J. M. Chussing, and J. M. Hyman, "Bifurcation Analysis of A Mathematical Model for Malaria Transmission," Siam J. Appl. Math, vol. 67, no. 1, pp. 24-45, 2006.

[4] P. B. Bloland and H. . Williams, Malaria Control During Mass Population Movements and Natural Disasters. Washington: The National Academies Press, 2002.

[5] L. Schwartz, G. V. Brown, B. Genton, and V. S. Moorthy, "A Reiew of Malaria Vaccine Clinical Projects Based on the WHO Rainbow Table," Malar. J., vol. 11, 2012.

[6] N. Chitnis, J. M. Hyman, and J. M. Cushing, "Determining Important Parameters in the Spread of Malaria Through the Sensitivity Analysis of a Mathematical Model," Bull. Math. Biol., vol. 70, no. 5, pp. 1272-1296, Jul. 2008, doi: 10.1007/s11538-008-9299-0. [Online]. Available: http://link.springer.com/10.1007/s11538-008-9299-0

[7] R. Resmawan and N. Nurwan, "Konstruksi Bilangan Reproduksi Dasar pada Model Epidemik SEIRS-SEI Penyebaran Malaria dengan Vaksinasi dan Pengobatan," J. Mat. Integr., vol. 13, no. 2, p. 105, Sep. 2017, doi: 10.24198/jmi.v13.n2.12332.105-114. [Online]. Available: http://jurnal.unpad.ac.id/jmi/article/view/12332

[8] P. van den Driessche and J. Watmough, "Further Notes on the Basic Reproduction Number," in Mathematical Epidemiology, Victoria: Springer, 1945.

[9] F. B. Agusto, N. Marcus, and K. . Okosun, "Application of optimal control to the epidemiology of malaria," Electron. J. Differ. Equ., vol. 8, no. 1, pp. 1-22, 2012.

[10] P. Johansson and J. Leander, Mathematical Modeling of Malaria: Methods for Simulation of Epidemics. Gothenburg: Chalmers University of Technology, 2010. 